\title{
ВИДИ ТА УМОВИ РОЗВИТКУ СИСТЕМИ ДЕРЖАВНОГО РЕГУЛЮВАННЯ ВИТРАТАМИ ПІДПРИЕМНИЦТВА
}

\begin{abstract}
Доведено, щ⿻ політика державного регулювання витратами підприємництва має формуватися на принципах забезпечення пріоритетності краӥни на міжнародних ринках, вирішення важливих сочіальних проблем суспільства, зростання добробуту населення. Розглянуто вплив державного регулювання витратами підприємницького сектору та їх класифікацію, яка проявляється у різноманітних видах, формах, методах та інструментах, а саме: тарифне регулювання; економічне регулювання, організачійно-інформаційне регулювання; нормативно-правове регулювання. Запропоновано умови розвитку системи державного регулювання витратами підприємництва. Дослідження умов розвитку системи державного регулювання витратами підприємництва свідчить про їх важливість та активну роль державних інститутів та інституцііонального середовища в економічному розвитку краӥни.
\end{abstract}

Ключові слова: види державного регулювання витратами підприємництва, умови розвитку державного регулювання витрат, чинники та інструменти регулювання витратами, державні інститути регулювання витратами, заходи державної політики регулювання витратами.

Постановка проблеми. В нашій країні актуальність проблеми управління витратами підприємництва в сучасних мінливих умовах ринкового реформування національної економіки додатково визначається об'єктивною необхідністю у забезпеченні оперативного й ефективного реагування суб'єктів підприємництва на перетворення господарського середовища, створенні належних організаційноекономічних засад підвищення ефективності виробництва конкурентоспроможної продукції в умовах загострення ринкового суперництва.

Створення впорядкованої структури державного регулювання витратами підприємництва вимагає здійснення економічно обгрунтованої їх класифікації за окремими ознаками. Слід відмітити, що в короткостроковому періоді державне регулювання витратами підприємництва шляхом прямого регулювання цін може забезпечувати стабілізацію економіки країни.

Аналіз останніх досліджень i публікацій. Сучасні дослідники звертають увагу на множинність цілей державного регулювання економікою, а саме: досягнення збалансованого зростання економічної системи, вирішення соціально-економічних проблем розвитку національної економіки, забезпечення ефективного

(c) Колісник Галина Миколаївна, д.е.н., доцент, професор кафедри обліку i аудиту, ДВНЗ «Ужгородський національний університет», м. Ужгород, тел.: 0501930067, email: halyna.kolisnyk@ uzhnu.edu.ua

Штулер Ганна Гордіївна, ст. викладач кафедри обліку і аудиту, ДВНЗ «Ужгородський національний університет», м. Ужгород, тел.: 0502625458, email: hanna.shtuler@uzhnu.edu.ua функціонування ринків, реалізація пріоритетів державної економічної політики та низка інших[1, с.66].

Л. І. Дідківська та Л. С. Головко наголошують на чотирьох головних цілях державного регулювання економікою, а саме (1) раціональне використання ресурсів; (2) стабільний розвиток національної економіки; (3) забезпечення конкурентоспроможності товарів на зовнішньому ринку; (4) реалізація соціальних цілей розвитку суспільства [2, с.38].

Проте окрім окреслених провідними науковцями цілей державного регулювання витрат підприємництва країни, що на сьогодні $\epsilon$ надзвичайно актуальним питанням, на нашу думку, необхідно також враховувати умови розвитку системи державного регулювання витратами підприємництва.

Тому основною метою формування ефективної системи державного регулювання витратами підприємницького сектору $є$ сукупність взаємопов'язаних методів, видів, засобів та умов для здійснення заходів підтримуючої, компенсаційної та регулюючої діяльності держави в процесі цілеспрямованого впливу на формування витрат підприємницького сектору економіки країни.

Обгрунтування видів ефективного державного регулювання витратами підприємницького сектору та визначення конкретних об'єктів цілеспрямованого впливу 3 боку держави та способів його здійснення, що дасть можливість визначити структуру підприємницького сектору економіки за критерієм фактору концентрації витрат. 3 урахуванням витрат, які несе підприємницький сектор економіки при здійсненні суспільного виробництва, визначено структуру підп- 
риємницького сектору шляхом розподілення його на такі внутрішні комплексні блоки, як енергоємне виробництво та трудомістке виробництво.

Формування цілей статті. Мета статті полягає у дослідженні ефективної системи державного регулювання видів та умов розвитку витратами підприємницького сектору країни.

Опис основного матеріалу дослідження. Основна цільова функція державного регулювання обумовлюється особливостями об'єкта регулювання, проблемами його розвитку та методами їх вирішення. Реалізація державного регулювання розвитком підприємництва здійснюється 3 допомогою видів, методів та умов. Правильне застосування видів, форм, методів та умов регулювання надає можливість досягнути відповідних результатів. Під ними розуміємо способи впливу держави на поведінку суб'єктів підприємництва 3 метою створення та забезпечення умов їхньої діяльності відповідно до визначених напрямів розвитку. Вони знаходить своє застосування через сукупність відповідних інструментів, які $€$ знаряддям для досягнення визначених цілей.

Класифікація витрат потрібна для моделювання впливу державного регулювання ними у підприємницькому секторі. Характерним для класифікації державного регулювання витрат підприємницького сектору є те, що держава надає підприємництву суспільні блага i послуги, які відповідають його потребам і характеризуються найбільш високими показниками ефективності, тому використання державного регулювання витратами підприємництва надає змогу критично оцінити напрями витрачання коштів підприємств.

Вплив державного регулювання витратами підприємницького сектору надає можливості здійснювати оцінювання фінансового стану держави завдяки можливості маневрування наявними в ii розпорядженні ресурсами, при цьому підвищується відповідальність державних органів за досягнення кінцевого кількісного та якісного результату діяльності підприємств.

Обгрунтування видів ефективного державного регулювання витратами підприємницького сектору та визначення конкретних об'єктів цілеспрямованого впливу 3 боку держави та способів його здійснення надасть можливість визначати структуру підприємницького сектору економіки за критерієм фактору концентрації витрат. 3 урахуванням витрат, які несе підприємницький сектор економіки при здійсненні суспільного виробництва, можна визначити структуру підприємницького сектору, розподіливши його на такі внутрішні комплексні блоки як енергоємне виробництво та трудомістке виробництво.

Відповідно до секторального розподілу за критерієм фактору концентрації витрат у підприємницькому секторі економіки найсуттєвіший вплив на обсяг витрат в енергоємному виробництві підприємницького сектору становлять тарифи на енергоресурси, тепло - та водопостачання, які встановлюються i визначаються на рівні уряду, а на обсяг витрат в трудомісткому виробництві найбільше впливають розміри соціальних стандартів для найманих працівників, які встановлюються державою, вони є обов'язковими для дотримання i визначають розміри оплати праці найманих працівників, яка $€$ частиною собівартості кінцевого продукту суб'єктів підприємництва.

Реалізація державного регулювання витратами підприємництва здійснюється 3 допомогою методів та інструментів. Правильне застосування методів регулювання надає можливість досягнути відповідних результатів. Під ними розуміємо способи впливу держави на поведінку суб'єктів підприємництва 3 метою створення та забезпечення умов їхньої діяльності відповідно до визначених напрямів розвитку. Кожен метод знаходить своє застосування через сукупність відповідних інструментів, які $\epsilon$ знаряддям для досягнення визначених цілей.

Політика державного регулювання витратами підприємництва має формуватися на принципах забезпечення пріоритетності країни на міжнародних ринках, вирішення важливих соціальних проблем суспільства, зростання добробуту населення. Розглянемо вплив державного регулювання витратами підприємницького сектору та їх класифікацію, яка проявляється у різноманітних видах, формах, методах та інструментах, а саме: тарифне регулювання; економічне регулювання, організаційноінформаційне регулювання; нормативно-правове регулювання.

Тарифне державне регулювання витратами підприємництва здійснюється шляхом регулювання цін у високомонополізованих галузях, таких як: енергетично-паливні підприємства та водопостачання i водовідведення. Тарифне регулювання - це система послідовних дій, заходів, організаційних i управлінських рішень, спрямованих на узгодження економічних інтересів виробників продукції, робіт та послуг, ціни і тарифи на які підлягають державному регулюванню, $з$ одного боку, і споживачів продукції, робіт, послуг, 3 іншого боку.

Розробка системи тарифів в Україні була розпочата разом із підготовкою у 1993 р. 


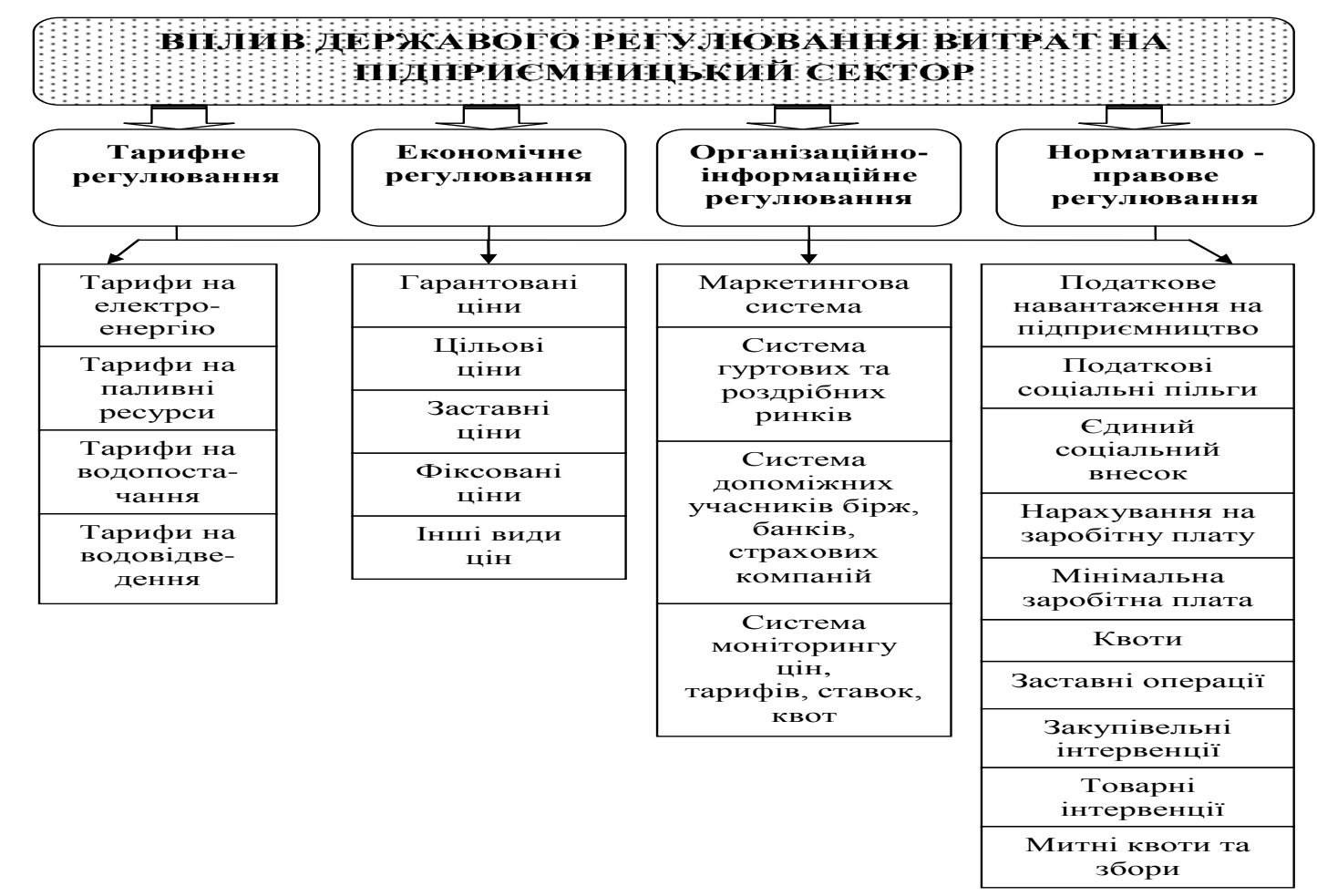

\section{Рис. 1. Види державного регулювання витратами на здійснення підприсмницької діяльності* *Розроблено авторами}

Положення про державне регулювання тарифів на електричну і теплову енергію. 3 того часу у сфері тарифоутворення з'явилося чимало прогресивних методик, наприклад методика розрахунку роздрібних тарифів на електроенергію, диференційованих за рівнями напруги споживачів; методика встановлення знижки до тарифів на електроенергію за участь споживачів у зменшенні дефіциту електричної потужності в енергосистемі; методика встановлення екологічної складової до тарифів на електричну енергію тощо [3, с.108]. При застосуванні економічного регулювання витратами підприємництва необхідно відмітити, що здійснення його відбувається на рівні економічної політики країни. Економічні методи державного регулювання витратами здійснюють опосередкований вплив на економічні інтереси суб'єктів підприємництва та зумовлюють їхню поведінку, при цьому не обмежують їх підприємницький вибір. Економічні методи регулювання підприємництва реалізуються за допомогою монетарних та фінансових інструментів. Вибір тих чи інших економічних інструментів залежить від ситуації в країні, розвиненості ринкових відносин та доктрини економічної політики, впливу економічного регулювання витратами підприємництва, підвищення чи зниження податкових ставок, їх диференціація для різних категорій платників податків, розширення чи звуження бази оподаткування, надання податкових пільг чи податкових кредитів тощо. Податковими інструментами $\epsilon$ : податкові канікули, база оподаткування, вид та розмір податкових ставок, податкові пільги.

Організаційно-інформаційне регулювання витратами підприємництва здійснюється шляхом моніторингу для інформування виробників, торгових мереж, переробних та заготівельних підприємств 3 метою ефективного формування їх купівельної та збутової політики. Ефективність від організаційно-інформаційного регулювання витратами підприємництва зумовлена якістю інформації (вхідної і вихідної), що $є$ необхідним для функціонування підприємств різного рівня.

Важливе місце в акумулюванні грошових коштів належить фінансовим посередникам, тому організаційно-інформаційне регулювання витратами підприємництва здійснюється завдяки інвесторам (кредиторам) всіх сфер національної економіки. В розвинених країнах світу провідну роль у фінансуванні суб'єктів економіки відіграють фінансові посередники.

Наявність ефективних фінансових посередників (банків, страхових компаній, недержавних пенсійних фондів, кредитних спілок та інших фінансових установ) $\epsilon$ необхідною передумовою розвитку інших секторів економіки країни, сприяє стабільному та прогнозованому функціонуванню всіх економічних процесів у суспільстві. В Україні фінансові посередники також $\epsilon$ потужним 
джерелом інвестицій в економіку, оскільки акумулюють значні обсяги коштів.

Нормативно-правове регулювання витратами підприємництва здійснюється на основі дієвих інструментів державного регулювання. До цих інструментів належать податкові важелі впливу. Використання податків у системі державного регулювання грунтується на властивих їм функціях: фіскальній та регулюючій. Використання податкових інструментів має на меті досягнення бажаної чи зміну діючої поведінки платників податків, що дозволяє у довгостроковій перспективі досягти певних цілей соціально-економічного розвитку суспільства, а у короткостроковій - бажаної поведінки платників податків.

Регулюючий вплив податків проявляється шляхом застосування таких методів: підвищення чи зниження податкових ставок, їх диференціація для різних категорій платників податків, розширення чи звуження бази оподаткування, надання податкових пільг чи податкових кредитів тощо. Податковими інструментами $\epsilon$ : податкові канікули, база оподаткування, вид та розмір податкових ставок, податкові пільги. Податковим кодексом України затверджено 18 загальнодержавних та 5 місцевих податків і зборів. Обгрунтуванням нормативноправового регулювання, $\epsilon$ те, що на макрорівні державне регулювання витратами здійснюється правовими та адміністративними методами шляхом встановлення тарифів на використання енергоресурсів і водних ресурсів та соціальних стандартів, а також розмірів відрахувань.

На мезорівні управління витратами підприємницького сектору здійснюється в межах секторального розподілу національної економіки, кластерних об'єднань в підприємницькому секторі, галузей та підгалузей національного господарства. При цьому необхідно забезпечити співвідношення інтересів держави та суб’єктів підприємництва.

Таблиця 1

Умови розвитку системи державного регулювання витратами підприсмництва [4, с.21]

\begin{tabular}{|c|c|c|}
\hline № & Умови & 3міст \\
\hline 1 & Економічні & Зменшення показників інфляції, безробіття \\
\hline 2 & Соціальні & $\begin{array}{l}\text { Зростання величини заробітної плати, покращення умов праці, морального } \\
\text { задоволення від праці, соціального захисту роботодавцем (охорона здоров'я, } \\
\text { збереження робочих місць, розвиток соціально-економічної сфери), підготовка, } \\
\text { перепідготовка та підвищення кваліфікації працівників за рахунок роботодавця }\end{array}$ \\
\hline 3 & Політичні & Взаємозв'язок між підприємництвом, олігархічними утвореннями та державою \\
\hline \multirow[t]{2}{*}{4} & \multirow[t]{2}{*}{ Податкові } & Спрощення системи збору податків та платежів \\
\hline & & Зниження податкового навантаження \\
\hline \multirow[t]{5}{*}{5} & \multirow[t]{5}{*}{$\begin{array}{l}\text { Адміністративні- } \\
\text { правові }\end{array}$} & $\begin{array}{l}\text { Створення нормального правового середовища, усунення бар'єрів при реєстрації } \\
\text { чи зміні статусу підприємства }\end{array}$ \\
\hline & & $\begin{array}{l}\text { Ліцензування, сертифікація, дозвільна система, реєстрація товарних знаків, } \\
\text { нормативні вимоги }\end{array}$ \\
\hline & & Перевірки, санкції за порушення, погодження \\
\hline & & Захист суб’єктів економічної діяльності, захист прав власності \\
\hline & & Справедлива та ефективна приватизація \\
\hline 6 & Ринкові & Зростання обсягів попиту на внутрішньому та зовнішньому ринках \\
\hline 7 & Фінансові & Удосконалення механізму фінансування і кредитування \\
\hline 8 & Інформаційні & Належне інформаційне і консультаційне забезпечення \\
\hline 9 & Інвестиційні & Створення та забезпечення сприятливого інвестиційного середовища \\
\hline 10 & Неформальні & Зменшення тіньової економіки, корупції тощо \\
\hline
\end{tabular}

Економічні умови. В результаті зменшення інфляції, безробіття, зростає загальний рівень життя населення. Підприємницькі структури зазнають втрат внаслідок скорочення збуту, результативність господарської діяльності зменшується, а сума загальних витрат підприємства зростає. Це в першу чергу відбивається на спаді пропозиції на попит товарів, робіт і послуг, зниженні купівельної спроможності населення, нестачі робочих місць. Завдання забезпечення загальноекономічних умов функціонування підприємництва покладено на численні організації, які формують інфраструктуру ринку. До таких організацій відносяться: банки, біржі, страхові компанії, лізингові фірми, консалтингові фірми, регіональні центри зайнятості тощо.

Не менш важливими є соціальні умови, які визначають ставлення окремих індивідуумів, де їхній кваліфікаційний рівень впливає на ставлення як до фахівців, а також на величину заробітної плати. Запропоновані умови праці мають приносити задоволення. Підприємець i працівник повинні приймати участь у вирішенні 
соціальних питань стосовно себе i своїх співробітників, їх охорони здоров'я, збереження робочих місць, розвитку соціально-економічної сфери тощо. Важливу роль у формуванні соціальних умов відіграють підготовка, перепідготовка, підвищення кваліфікації працівників.

Політичні умови. Неефективна державна політика, недостатня державна підтримка проблемних секторів чи видів діяльності не сприяють розвиткові державного регулювання витратами підприємництва. На сьогодні в Україні існує тісний взаємозв'язок між крупним підприємництвом та олігархічними структурами, а у державних органів немає ефективної системи врегулювання відносин між ними. Адже всім відомо, що ефективне функціонування суб'єктів підприємництва $\epsilon$ передумовою економічного добробуту громадян країни, а відтак, і національної безпеки.

Податкові умови. Господарська діяльність підприємництва не може бути повноцінною за умови складної та незрозумілої системи збору податків та платежів. Спроба вирішення будьяких конфліктних ситуацій зі сплатою податків чи платежів призводить до залучення додаткових коштів для сплати та погашення прострочених виплат, нарахованої пені чи санкцій тощо. Зростання податкового навантаження на підприємницький сектор також призводить до зростання загальної суми витрат та до зниження рівня результативності підприємництва. Найбільша проблема податкового втручання в підприємницький сектор полягає в тому, що навантаження податкової системи нашої держави та іiі фіскальна спрямованість є чи не найбільш вагомим чинником стримування розвитку підприємств. 3 огляду на це, даний чинник не втрачає свого пріоритетного положення серед факторів виникнення кризи, створюючи передумови для погіршення фінансово-економічного становища підприємницького сектору економіки нашої країни.

Адміністративно-правові умови. Будь-яка підприємницька діяльність функціонує в межах відповідного правового середовища. Тому велике значення має створення необхідних правових умов для іiі розвитку. Це, в першу чергу, наявність законів, що регулюють підприємницьку діяльність, створюють найбільш сприятливі умови для ऑii розвитку. Правові норми повинні забезпечувати: спрощену і прискорену процедуру створення, та державної реєстрації підприємств, захист підприємців від державного бюрократизму; вдосконалювання податкового законодавства в напрямі мотивації виробничої підприємницької діяльності. Встановлені державою правила здійснення підприємницької діяльності у вигляді обмежень, дозволів та норм щодо здійснення певних видів діяльності призводять до того, що з їх виконанням у підприємців виникають витрати. Значна кількість законодавчих та інших нормативно-правових актів ускладнюють роботу підприємців, а часті їх зміни та доповнення заплутують їх, а в результаті збільшують витрати. Процедури створення, закриття бізнесу та отримання різноманітних дозволів для ix діяльності $\epsilon$ складними, громіздкими та довготривалими, що потребує їх спрощення.

Ринкові умови. Малий, середній i великий бізнес $є$ живильним середовищем нашої країни, однак, за умов обмеженого внутрішнього та зовнішнього попиту і наявність кризи в збуті ці види бізнесу можуть втрачати головних споживачів своєї продукції. В цьому випадку витрати підприємства можуть зростати за рахунок різного роду заходів щодо утримання позицій на ринку, а результативність підприсмства не змінюватися або й надалі знижуватися.

Фінансові умови. Механізми фінансування i кредитування підприємництва потребують прозорості та відкритості, в більшості випадків вони носять формальний характер. Дуже часто на практиці виявляється, що програми кредитнофінансової підтримки пріоритетних сфер діяльності відсутні або не працюють (чи працюють вкрай неефективно).

Інформаційні умови. Інформаційне i консультаційне забезпечення на рівні держави на сьогодні недосконалі, і потребують втручання держави на предмет підтримки підприємницького сектору економіки нашої країни. Саме тому, підприємства змушені запрошувати чи вдаватися до послуг консультантів та спеціалістів у певній сфері послуг. Відповідно додаткові послуги призводять до додаткових витрат та зниження загальної результативності.

Інвестиційні умови. Саме створення сприятливого інвестиційного клімату призводить до притоку іноземних капіталів і до «вливань» національних інвестиційних ресурсів в найбільш перспективні види підприємницької діяльності. За сприятливих умов загальна результативність підприємництва зростає. Результатом цього є достатня кількість інвестиційних ресурсів на внутрішньому ринку, поширення інвестиційних процесів.

Неформальні умови. Наявність неформальних умов в процесі господарської діяльності призводить до зниження результативності цієї діяльності. Це стосується зростання витрат на хабарі та неформальні платежі, штучно організована державна бюрократія тощо свідчать про те, що відсутність інституціонального середовища негативно впливає на формування витрат підп- 
риємництва. За створення несприятливих умов господарської діяльності підприємці ухилятимуться від виконання нормативно встановлених правил та норм на користь більш вигідних неофіційних угод та домовленостей. Саме неформальні платежі призводять до зростання обсягів витрат, знижуючи ефективність підприємництва, нівелюючи зацікавленість у підвищенні якісних і кількісних показників бізнесу [4, с.22].

Дослідження умов розвитку системи державного регулювання витратами підприємництва свідчить про їх важливість та активну роль державних інститутів та інституціонального середовища в економічному розвитку країни. Виділення та систематизація інституціональних умов розвитку регулювання витратами підприємництва на макроекономічному рівні надає можливість виділити проблемні напрями інституціональних перетворень, оскільки всі дослідники, котрі займаються цією проблематикою, заявляють про їх наявність. 3 нашого боку в процесі дослідження розкриємо низку формальних та неформальних взаємовідносин між суб' єктами підприємництва і державою, в результаті яких утворився цілий ряд так званих «інституційних пасток», що нівелють підтримку пріоритетних видів економічної діяльності, інформаційну прозорість та забезпечення правового захисту підприємництва [4, с.22].

Очевидно, що перераховані вище умови не можуть бути цілком відмінені. Можна говорити лише про їх впорядкування та врегулювання процедур ї проходження. Проте наукові дослідження і практика доводять, що в Україні постійно з'являються нові проблеми й перешкоди, які заважають розвиткові підприємництва.

Основні напрями непрямого державного регулювання витратами підприємництва в Україні повинні бути такими: прогнозовані закупки товарів і послуг; податкова політика - встановлення податкових ставок та бази оподаткування; тарифна політика - встановлення тарифів на користування електроенергією, водою, теплом і деякими комунікаційними послугами.

Висновки i перспективи подальших досліджень. Отже, види та умови розвитку, які характеризують державне регулювання витратами підприємництва мають бути спрямовані на ефективність функціонування та підтримку підприємництва країни:

1. В країнах зі стабільною ринковою економікою уряд, як правило, мало втручається в регулювання витратами, але повної свободи в питаннях формування цін немає і державне їхнє регулювання в тій чи іншій мірі існує в кожній 3 них. Це стосується тарифного державного регу- лювання витратами підприємництва у високомонополізованих галузях, таких як: енергетичнопаливні підприємства та водопостачання i водовідведення.

2. Економічне регулювання витратами підприємництва характерне для податкового навантаження, а раціональна податкова система $\epsilon$ одним із фінансових важелів впливу на витрати підприємництва, за допомогою якого можна досить ефективно впливати на процеси економічного зростання та соціального розвитку підприємницького сектору. Правильно сформована податкова система забезпечує умови активізації для підприємницької діяльності і сприяє розвиткові національного виробництва та нарощення підприємствами експортного потенціалу. Податки на сьогодні - це найбільший тягар, який лягає на підприємництво і на кінцевого споживача. Вагомим $€$ i той факт, що і нарахування на заробітну плату та утримання із заробітної плати мають значення для регулювання платоспроможного попиту населення. Тому при розробці податкового навантаження, необхідно враховувати рівень доходів населення.

Ступінь, форми та масштаби державного втручання в ціноутворення залежить від стану економічного розвитку країни, інтенсивності інфляційних процесів, ступеня монополізації та конкуренції, інших чинників. Це стосується організаційно-інформаційного регулювання витратами підприємництва, яке здійснюється шляхом моніторингу для інформування виробників, торговельних мереж, переробних та заготівельних підприємств 3 метою ефективного формування їх купівельної та збутової політики. Наявність ефективних фінансових посередників (банків, страхових компаній, недержавних пенсійних фондів, кредитних спілок та інших фінансових установ) $\epsilon$ необхідною передумовою розвитку інших секторів економіки країни, сприяє стабільному та прогнозованому функціонуванню всіх економічних процесів у суспільстві. В Україні фінансові посередники також $\epsilon$ потужним джерелом інвестицій в економіку, оскільки акумулюють значні обсяги коштів. Під час кризових ситуацій, руйнування грошовофінансових систем, значного дефіциту товарів і великого надлишку грошей в обігу державне втручання має бути більш жорстким та об'ємним.

3. Слід визнати виняткове значення державного регулювання витратами підприємництва для вирішення нагальних проблем державотворення шляхом унормування відповідних критеріїв, наприклад, таких як: прогнозований економічний ефект, позитивні соціальні наслідки, а також наявність у програмі належним чином 
обгрунтованих інвестиційної та інноваційної складових. Необхідно вдосконалити нормативноправову базу, яка визначатиме державне регулювання витратами підприємництва в частині його методологічного забезпечення, розробити методичні рекомендації щодо оцінювання ефективності та результативності державного регулювання витратами підприємництва. Адже відсутність єдиної методики оцінювання ефективності робить цей процес формальним.

4. Потрібно приділяти більше уваги функціонуванню інформаційних систем, а саме ïх технічним можливостям, оскільки своєчасне надання даних, необхідних для ефективного аналізу, оцінювання результатів і впровадження системи звітності, $є$ платформою для реалізації програмно-цільового підходу до регулювання витратами. Результатом державного регулювання витратами підприємництва має стати імплементація в діючу систему регулювання виваженої політики уряду нашої країни, спрямованої на створення оптимальних умов ведення підприємницької діяльності - впровадження дієвої системи управління витратами. Метою та сутнісною характеристикою такої системи управління витратами, на наше переконання, має стати створення чітких і прозорих механізмів для впровадження послідовних та орієнтованих на досягнення конкретних цілей вищенаведених кроків.
5. Систематизація та виділення умов розвитку регулювання витратами підприємництва на макро рівні надає можливість виділити проблемні аспекти інституціональних перетворень. 3 нашого боку, в процесі дослідження розкриємо низку формальних та неформальних взаємовідносин між суб'єктами підприємництва i державою, в результаті яких утворився цілий ряд так званих «інституційних пасток», що нівелють підтримку пріоритетних видів економічної діяльності, інформаційну прозорість та забезпечення правового захисту підприємництва.

Отже, удосконалення практики державного регулювання видів та умов розвитку державного регулювання витратами підприємництва має сприяти створенню системи ефективного державного управління. Однак сьогодні Україна до цього повною мірою не готова. Адже міністерства та відомства не завжди до кінця розуміють суть державного регулювання витратами підприємництва, що передбачає не просто реалізацію стратегії управління на підприємствах, а й призведе до стабільного зростання валового внутрішнього продукту. Ця неготовність проявилася у двох аспектах - в неготовності самих державних структур до введення державного регулювання витратами підприємництва і його неготовності швидко адаптуватися до нововведень.

\section{ПЕРЕЛІК ВИКОРИСТАНИХ ДЖЕРЕЛ}

1. Нікішина О. В. Концептуальні засади державного регулювання інтегрованого зернового ринку / О.В. Нікішина // Економіка харчової промисловості. - 2014. - № 1 (21). - С. 64-72.

2. Дідківська Л.І. Державне регулювання економіки / Л.І. Дідківська, Л.С. Головко. - К.: Знання, 2008. $213 \mathrm{c}$.

3. Шевчук В.Р., Перфілова О.С. Удосконалення системи тарифів як необхідна передумова переходу до економічних методів державного регулювання в електроенергетиці України / В.Р. Шевчук, О.С. Перфілова // Економіка промисловості. - 2011. - № 1. - С. 104-111.

4. Колісник Г. М. Інституціональні умови та пастки розвитку регулювання витратами підприємництва: [Текст] / Колісник Г. М. // Наукові записки Національного університету «Острозька академія». Серія «Економіка»: науковий журнал. - Острог: Вид-во НУ«ОА», вересень 2016. - № 2(30). - 142 с. - С. 19 - 26.

\section{REFERENCES}

1. Nikishina, O.V. (2014). Kontceptualni zasadi derzhavnogo reguliuvannia integrovanogo zernovogo rinku [Conceptual bases of state regulation of the integrated grain market] Ekonomika kharchovoi promislovosti - The economy of the food industry, 1 (21), 64-72 [in Ukrainian].

2. Didkivska, L.I. (2008). Derzhavne reguliuvannia ekonomiky [State regulation of the economy]. K.: Znannia [in Ukrainian].

3. Shevchuk, V.R., \& Perfilova, O.Ye. (2011). Udoskonalennia sistemi tarifiv iak neobkhidna peredumova perekhodu do ekonomichnikh metodiv derzhavnogo reguliuvannia v elektroenergetitci Ukraini [Improvement of the tariff system as a prerequisite for the transition to economic methods of state regulation in the power engineering industry of Ukraine]. Ekonomika promislovosti - The economy of industry, 1, 104-111 [in Ukrainian].

4. Kolisnik, G.M. (2016). Institutcionalni umovi ta pastki rozvitku reguliuvannia vitratami pidpriemnitctva [Institutional conditions and traps of entrepreneurship expenses regulation development]. Naukovi zapiski Natcionalnogo universitetu «Ostrozka akademiia». Seriia «Ekonomika»: naukovii zhurnal - Scientific notes of the National University "Ostroh Academy". Series "Economics": a scientific journal, 2 (30), 19-26 [in Ukrainian]. 